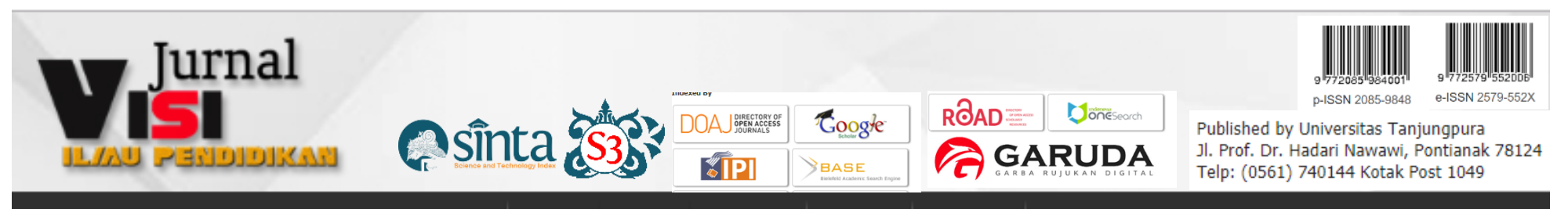

\title{
ANALISIS PERENCANAAN PEMBELAJARAN MAHASISWA PROGRAM STUDI PENDIDIKAN SOSIOLOGI
}

\author{
Imran, Gst. Budjang \\ Pend. Sosiologi FKIP Universitas Tanjungpura \\ Email: bud111254@yahoo.co.id
}

\begin{abstract}
This study aimed to describe: 1) the ability of prospective students of the Sociology Education Study Program FKIP Untan in designing lesson plans according to the 2013 curriculum, and 2) the constraints of students in Sociology Education Study Program as prospective teacher in designing lesson plans according to the 2013 curriculum. The type of research was a qualitative descriptive study with a data collection tool in the form of an observation sheet with assessment rubrics and interview guidelines. The research was conducted from June to October 2018. The subjects in this study were sociology education students who took Field Experience Program-2 (PPL-2)courses. Data analysis consists of reduction, presentation of data, and conclusion. The results of the study concluded that the abilities of prospective students of Sociology Education Study Program FKIP Untan in designing lesson plan according to the 2013 curriculum were as follows: $a$. Writing down the completeness of the lesson plan identity was categorized as very well, $b$. The completeness of the lesson plan component was categorized as very well, c. The formulation of core competencies, basic competencies, and GPA were categorized as poor, $d$. The formulation of learning objectives was categorized as poor, e. Teaching material was categorized as fair, f. Model / Learning Method was categorized as good, g. Learning Media was categorized as very good, h. Learning Resources were categorized as good, and $i$. The formulation of Learning Outcomes Assessment was categorized as good.
\end{abstract}

Kata kunci: Instructional Design, PPL Students, Sociology Education

\section{PENDAHULUAN}

Dalam rangka mencapai mencerdaskan kehidupan bangsa dan mengembangkan manusia seutuhnya, maka sangat dibutuhkan peran pendidik yang profesional (Pupuh Fathurrohman, 2012). Sesuai dengan UndangUndang Republik Indonesia Nomor 20 Tahun 2003 tentang Sistem Pendidikan Nasional, jabatan guru sebagai pendidik merupakan jabatan professional. Untuk itu, profesional guru dituntut agar terus berkembang sesuai dengan perkembangan zaman, ilmu pengetahuan dan teknologi serta kebutuhan masyarakat termasuk sumber daya manusia yang berkualitas dan memiliki kapabilitas untuk mampu bersaing baik ditingkat regional, nasional maupun internasional. Menurut Undang-Undang Republik Indonesia Nomor 14 Tahun 2005 tentang Guru dan Dosen, guru harus memiliki kompetensi pedagogik, kompetensi kepribadian, kompetensi sosial, dan kompetensi profesional.

Tugas, fungsi, dan peran guru dalam pembelajaran selaras dengan hakekat bahan 
ajar yang disajikan. Mencerdaskan kehidupan bangsa memiliki peran penting dalam meningkatkan kualitas pendidikan. Kualitas tersebut dapat ditingkatkan melalui peningkatan profesionalisme guru yang mengutamakan tugas dengan tanggung jawab serta memahami tugas dan fungsinya sebagai pendidikan. Tugas guru sebagai guru mata pelajaran diantaranya adalah merencanakan pembelajaran sebelum melaksanakan pembelajaran, yaitu mengembangkan perangkat pembelajaran.

Keterampilan mahasiswa dalam mengembangkan perangkat pembelajaran akan diuji dalam kegiatan Praktek Pengelaman Lapangan (PPL). Kegiatan PPL diharapkan mahasiswa memiliki pengalaman langsung, bagaimana menyelenggarakan kegiatan pengajaran pada satu satuan pendidikan baik SD, SMP atau SMA. Penyelenggaraan PPL sendiri hanya berlaku bagi mahasiswa Program Sarjana (S1). Kemampuan mengajar adalah sesuatu yang dimiliki untuk memenuhi tugas atau pekerjaan yang dibebankan kepadanya, dalam hal ini pekerjaan dan beban kaitan dalam mengajar. Kemampuan mengajar mahasiswa PPL merupakan serangkaian kegiatan mahasiswa dalam praktek latihan mengajar pada salah satu satuan pendidikan. Program PPL bagi mahasiswa menjadi sarana pembelajaran mahasiswa dan mengaplikasikan keseluruhan kemampuannya dalam mengelola kelas dan menye-lenggarakan kegiatan pengajaran berdasarkan teori-teori yang sudah diperoleh di bangku kuliah. Bekal pengalaman mengajar itu langsung dipraktekkan pada siswa pada masing-masing satuan pendidikan akan memberikan pengalaman nyata bagi mahasiswa kelak ketika mahasiswa akan menjadi guru sesungguhnya.

Mata kuliah PPL pada Program Studi
Pendidikan Sosiologi FKIP Untan terdiri dari PPL-1 dan PPL-2. Mahasiswa Program Studi Pendidikan Sosiologi diwajibkan mengikuti kedua mata kuliah tersebut dengan nilai minimal B. Perkuliahan PPL-1 berlangsung pada kampus FKIP Untan, sedangkan PPL-2 berlangsung pada satuan pendidikan yang berada di wilayah Pontianak dan sekitarnya. Kegiatan PPL-2 yang ditempuh oleh mahasiswa Program Studi pendidikan Sosiologi berlangsung pada semester gazal periode akademik Juli-Desember 2018. Program PPL-2 terselenggara di satuan pendidikan terkait dengan serangkaian kompetensi yang harus dikuasai dengan baik, antara laian: kompetensi menyusun Rencana Pelaksanaan Pembelajaran (RPP) selama satu semester.

Hasil penelitian Kharisma dan Hariyatmi (2015) disimpulkan bahwa kemampuan Pedagogical Knowledge (PK) Calon Guru Biologi FKIP UMS dalam menyusun RPP tahun ajaran 2015/2016 termasuk baik, ditunjukkan dengan kemampuan penggunaan metode/model 53,80\% (cukup), penggunaan berbagai macam metode/model 63,95\% (baik), jenis media pembelajaran 31,55\% (kurang), pemilihan media sesuai dengan kegiatan pembelajaran 93,75\% (sangat baik), menyusun alat evaluasi $48,10 \%$ (cukup), dan pemilihan ranah penilaian $73,85 \%$ (baik). Namun hasil penelitian Ambarawati (2016) ditemukan bahwa calon guru pendidikan matematika membuat rencana pelaksanaan pembelajaran (RPP) dengan sangat baik, tetapi belum tercapai secara optimal pada indikator metode pembelajaran dan langkah-langkah pembelajaran. Kedua hasil penelitian ini menunjukkan ada perbedaan kemampuan mahasiswa calon guru dalam merancang RPP.

Kegiatan PPL-2 yang dilaksanakan 
mahasiswa Program Studi Pendidikan Sosiologi tidak jarang menghadapi permasalahan atau kendala-kendala ketika di sekolah. Sari, et. al (2013) dalam kegiatan observasinya menemukan bahwa mahasiswa praktikan dalam melaksanakan pengajaran terutama dalam mengelola kelas di sekolah latihan masih terdapat beberapa kendala, karena masih kurangnya pengalaman di lapangan dan persiapan sebelum melaksanakan praktik mengajar. Meskipun mahasiswa sudah dibekali dengan berbagai persiapan dini sebelum melaksanakan praktik baik materi maupun kesiapan lainnya, praktikan masih juga mendapat kendala-kendala dalam mengelola kelas sehingga pengalaman yang didapatkan dalam praktik mengajar tidak dapat diperoleh secara maksimal.

Agar lebih jelas tentang kemampuan mahasiswa calon guru Sosiologi FKIP Untan dalam merancang RPP, maka sangat urgen dilakukan penelitian tentang analisis perencanaan pembelajaran mahasiswa PPL Program Studi Pendidikan Sosiologi di Sekolah Latihan Tahun 2018. Melalui penelitian ini diharapkan mendapatkan gambran yang jelas tentang kemampuan mahasiswa PPl Program Studi Pendidikan Sosiologi dalam merancang RPP dan kendalakendala yang dihadapi mahasiswa dalam merancang RPP.

\section{METODE PENELITIAN}

Jenis penelitian ini merupakan penelitian deskriptif kualitatif. Arikunto (2010) menjelaskan bahwa penelitian deskriptif merupakan penelitian yang dirancang untuk memperoleh informasi tentang status suatu gejala yang terjadi dilapangan pada saat penelitian dilakukan. Penelitian ini dilaksanakan pada bulan Juni sampai dengan
Oktober 2018. Tempat penelitian adalah Sekolah Menengah Negeri Atas Kota Pontianak. Subyek dalam penelitian ini adalah mahasiswa pendidikan sosiologi yang mengambil mata kuliah PPL-2. Alat pengumpul data yang digunakan dalam penelitian ini adalah: 1) Lembar pengamatan disertai rubrik penilaian, 2) Pedoman wawancara, 3) dokumentasi. Lembar pengamatan disertai rubrik penilaian digunakan untuk menganalisis kemampuan merencanakan pembelajaran pada mahasiswa Program Studi Pendidikan Sosiologi yang melaksanakan PPL-2 di Sekolah Menengah Negeri Atas Kota Pontianak. Selanjutnya hasil analisis dikategorikan kemampuannya. Wawancara digunakan untuk menggali informasi kendala mahasiswa Program Studi Pendidikan Sosiologi dalam melaksanakan PPL-2 di Sekolah Menengah Negeri Atas Kota Pontianak. Wawancara mengacu dari hasil lembar observasi. Wawancara juga dilakukan pada siswa untuk mengecek kemampuan mahasiswa dalam melaksanakan pembelajaran. Dokumentasi digunakan untuk mendukung data-data dari lembar observasi dan wawancara yang telah didapat sebelumnya. Dokumentasi yang diperlukan dalam penelitian ini adalah RPP yang dibuat guru sosiologi

Keabsahan data dalam penelitian ini melalui triangulasi metode karena dalam penelitian ini proses pengecekan data dilakukan dengan lebih dari satu metode yaitu dengan metode observasi dan wawancara. Kegiatan yang dilakukan yaitu dengan memeriksa ulang data yang telah didapat dari hasil observasi dan hasil wawancara. Teknik analisis data yang digunakan dalam penelitian ini yaitu analisis data kualitatif yang meliputi: (1) Reduksi data yaitu memilih hal-hal pokok 
kemudian difokuskan pada hal-hal yang penting dan membuang hal-hal yang tidak penting, (2) Penyajian data yaitu menyajikan data dalam bentuk uraian singkat, bagan, maupun grafik, (3) Penarikan kesimpulan dimaksudkan untuk memberi kesimpulan terhadap permasalahan yang dibahas (Sugiyono, 2010).

\section{HASIL PENELITIAN DAN PEMBAHASAN}

Hasil penelitian diperoleh dari analisis RPP yang mengacu pada pedoman telaah RPP Kurikulum 2013 yang diadopsi dari Lembar Kerja
Bimbingan Teknis Kurikulum 2013 dan telah dimodifikasi oleh peneliti. Hasil penelaahan tersebut, diperoleh nilai rata-rata RPP sebesar 80,60 . Hasil ini menunjukkan bahwa mahasiswa pendidikan Sosiologi FKIP Universitas Tanjungpura Pontianak sudah mampu dalam menyusun RPP berdasarkan Kurikulum 2013. Pada Grafik 4.1 juga menunjukkan sebanyak $46,15 \%$ mahasiswa berada pada kategori baik dan 53,85\% berada pada kategori cukup. Rekapitulasi persentase kategori tingkat ketercapaian kemampuan menyusun RPP pada mahasiswa dapat dilihat pada Grafik 1 dibawah ini.

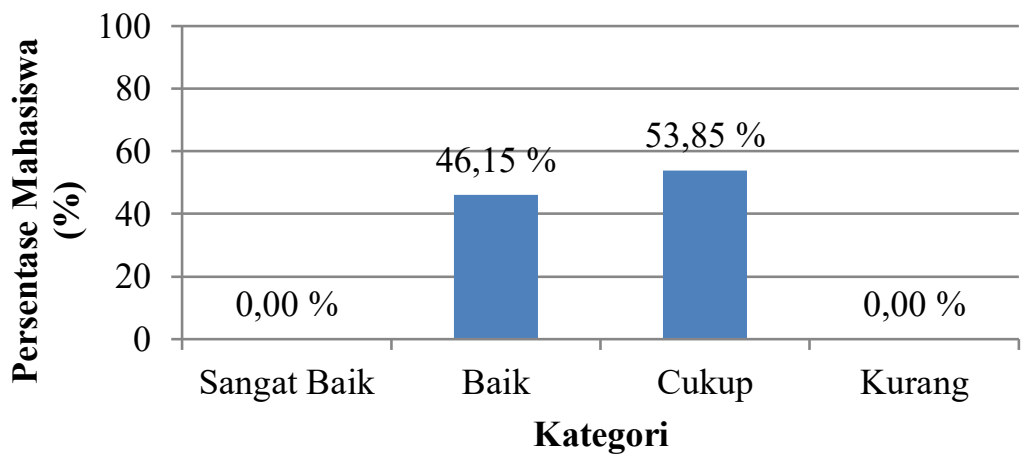

\section{Grafik 1. Persentase Kategori Tingkat Ketercapaian Kemampuan Menyusun RPP pada Mahasiswa Pendidikan Sosiologi}

RPP berdasarkan Kurikulum 2013 pada format penyusunannya terbagi kedalam beberapa komponen. Pada rubrik penilaian RPP, peneliti membagi kedalam 10 komponen/aspek RPP yang diukur. Secara rinci, perolehan persentase skor setiap komponen/aspek RPP dapat dilihat pada Tabel 2 berikut.

Tabel 2. Persentase Skor Komponen Utama RPP Berdasarkan Kategori

\begin{tabular}{lllll}
\hline No & Komponen/Aspek RPP & Kode & \% skor & Kategori \\
\hline 1 & Kelengkapan Identitas RPP & A & 100 & Sangat Baik \\
2 & Kelengkapan Komponen RPP & B & 97,4 & Sangat Baik \\
3 & Rumusan KI, KD dan IPK & C1 & 58,3 & Kurang \\
4 & Rumusan Tujuan Pembelajaran & C2 & 48,7 & Kurang \\
5 & Materi Ajar & C3 & 76,9 & Cukup \\
6 & Model/Metode Pembelajaran & C4 & 89,7 & Baik \\
7 & Media Pembelajaran & C5 & 92,3 & Sangat Baik \\
8 & Sumber Belajar & C6 & 71,8 & Cukup \\
9 & Kegiatan Pembelajaran & C7 & 85,4 & Baik \\
\hline
\end{tabular}




\begin{tabular}{lllll}
\hline 10 & Penilaian Hasil Belajar & C8 & 86,3 & Baik \\
\hline
\end{tabular}

Perencanaan pembelajaran yang disusun dalam bentuk rencana pelaksanaan pembelajaran (RPP) merupakan salah satu kompetensi pedagogik yang harus dimiliki oleh guru. Berdasarkan Permendikbud No 22 tahun 2016 tentang standar Proses Pendidikan Dasar dan Menengah, RPP adalah rencana kegiatan pembelajaran tatap muka untuk satu pertemuan atau lebih. Dengan demikian, mahasiswa Program Studi Pendidikan Sosiologi sebagai calon guru dituntut untuk mampu menyusun RPP sebagai persiapan menjadi guru yang profesional.

Berdasarkan hasil analisis data mengenai penyusunan RPP berdasarkan Kurikulum 2013, diketahui mahasiswa pendidikan sosiologi FKIP Universitas Tanjungpura mampu merencanakan pembelajaran dengan baik yang dibuktikan dari hasil analisis RPP dengan nilai 80,60. Kelengkapan komponen RPP yang disusun mahasiswa juga memperoleh persentase skor dengan kategori sangat baik yaitu 97,4\%. Kelengkapan komponen RPP ini meliputi 9 komponen utama RPP seperti 1) identitas RPP, 2) Rumusan Kompetensi Inti, Kompetensi Dasar dan Indikator Pencapaian Kompetensi, 3) Rumusan Tujuan Pembelajaran, 4)Materi Ajar, 5) Model dan Metode Pembelajaran, 6) Sumber belajar, 7) Langkah-langkah Pembelajaran, 8) Penilaian Hasil Belajar dan lampiran-lampiran pendukung. Berdasarkan hasil analisis data, sebanyak 7,69\% mahasiswa masih kurang melengkapi komponen RPP yakni Penilaian hasil belajar dan lampiran penilaian yang juga tidak dilampirkan

Berdasarkan hasil wawancara, mahasiswa mengutib KI ataupun KD dari silabus yang diperoleh dari sumber internet. Mereka juga tidak menyadari bahwa apa yang mereka cantumkan tidak sesuai dengan permendikbud. Lebih lanjut mereka tidak mengetahui bahwa rumusan KI dan KD dapat dikutib di Permendikbud no 24 Tahun 2016. Rumusan IPK yang merupakan kemampuan yang dapat diukur dan/atau diobservasi untuk disimpulkan sebagai pemenuhan KD pada KI-1, KI-2, KI-3 dan KI-4 harus dikembangkan berdasarkan $\mathrm{KD}$ dan menggunakan kata kerja operasional yang mengandung satu tindakan. Sehingga, hasil analisis IPK juga berpengaruh terhadap KD yang dicantumkan dalam RPP. Namun dalam penilaian peneliti mengikuti KD yang telah tercantum dalam RPP sehingga penilaian lebih terfokus pada komponen IPK. Hasil analisis data diperoleh kemampuan mahasiswa merumuskan IPK sebesar $73,1 \%$. Hal ini menunjukkan mahasiswa cukup mampu merumuskan IPK yang dikembangkan berdasarkan KD dan menggunakan kata kerja operasional.

Berdasarkan hasil wawancara, 69,2\% mahasiswa mengungkapkan tidak mengetahui persyaratan membuat IPK yang baik. Mereka hanya mengetahui bahwa IPK harus menggunakan kata kerja operasional. Hal ini dibuktikan dari analisis RPP, mahasiswa telah menggunakan kata kerja operasional namun beberapa masih mengandung lebih dari satu tindakan. Jika lebih dari satu tindakan, maka kemampuan peserta didik akan sulit diukur ketercapaian kompetensinya.

Perencanaan pembelajaran tidak lepas dari merumuskan tujuan pembelajaran. Seluruh kompetensi yang akan dicapai oleh peserta didik, gambaran proses pembelajaran dan pencapaian hasil pembelajaran dituangkan di tujuan pembelajaran dalam bentuk deskripsi yang dirumuskan berdasarkan KD. Secara keseluruhan, berdasarkan hasil analisis RPP, diperoleh persentase skor rumusan tujuan pembelajaran sebesar 48,7\%. Hal ini menunjukkan kemampuan mahasiswa pendidikan Sosiologi dalam merumuskan tujuan pembelajaran tergolong rendah.

Sebanyak 84,6\% mahasiswa telah membuat tujuan pembelajaran dalam bentuk dekripsi akan tetapi kurang tampak gambaran proses pembelajaran dan sebanyak 92,3\% mahasiswa hanya merumuskan kompetensi pengetahuan dan sikap yang akan dicapai saat pembelajaran. Dengan demikian mahasiswa masih belum mampu menyusun tujuan pembelajaran yang baik sesuai kurikulum berlaku. 
Hasil ini diperkuat dari wawancara terhadap mahasiswa yang mengatakan bahwa mereka tidak mengetahui secara lengkap persyaratan penyusunan rumusan tujuan pembelajaran yang terbaru sesuai kurikulum 2013. Mereka hanya mengetahui bahwa tujuan pembelajaran dibuat dalam bentuk deskripsi. Sehingga, rumusan tujuan pembelajaran yang dibuat mahasiswa belum mencirikan karakteristik kurikulum 2013.

Materi ajar yang termuat dalam RPP diidentifikasi dengan mengukur kesesuaian cakupan materi terhadap IPK dan adanya pembagian materi yang bersifat faktual, konseptual, prosedural dan metakognitif yang ditulis dalam bentuk butir-butir. Berdasarkan hasil analisis RPP, diperoleh persentase skor komponen materi ajar sebesar 76,9\%. Hal ini menunjukkan bahwa mahasiswa cukup mampu dalam menyusun materi ajar. Analisis data lebih lanjut, sebanyak 23,1\% mahasiswa masih menuliskan submateri saja. Berdasarkan hasih wawancara, mahasiswa tersebut tidak paham membagi materi kedalam 4 muatan yakni faktual, konseptual, prosedural dan metakognitif.

Model dan metode pembelajaran yang dipilih disesuaikan dengan tujuan pembelajaran dan karakteristik materi pembelajaran. Kriteria pemilihan strategi pembelajaran meliputi model dan metode pembelajaran yang disesuaikan dengan tujuan pembelajaran dan karakteristik materi pembelajaran yaitu berdasarkan pasal 2 UU RI No. 20 Tahun 2003 tentang sistem pendidikan nasional dan pasal 32 UUD 1945 (Mulyasa, 2014). Berdasarkan hasil analisis RPP, diketahui bahwa kemampuan mahasiswa dalam menentukan model dan metode pembelajaran tergolong baik dengan persentase skor sebesar $89,7 \%$.

Sebagian besar mahasiswa menggunakan model pembelajaran discovey learning. Mahasiswa memilih model pembelajaran ini karena merupakan model yang disarankan dalam kurikulum 2013 dan dapat menjadikan pembelajaran aktif. Menurut Sund (dalam Fathurrohman, 2015) model discovery ialah mengasimilasikan suatu konsep atau prinsip dengan mengamati berbagai hal di lingkungannya. Karakteristik materi pelajaran sosiologi sangat erat di lingkungan sekitar, sehingga model discovery learning menjadi salah satu model yang dapat dijadikan pedoman dalam kegiatan pembelajaran sosiologi.

Metode yang dipilih sebagian besar mahasiswa ialah metode yang bervariasi diantaranya diskusi, tanyajawab dan penugasan. Hal ini selaras dengan pendapat Kosasih (2014), mengingat karakteristik peserta didik yang beragam, metode yang digunakan hendaknya bervariasi. Sebanyak $84,6 \%$ mahasiswa menggunakan lebih dari dua metode dalam perencanaan pembelajaran.

Prinsip pokok yang harus diperhatikan dalam penggunaan media adalah bahwa media digunakan dan diarahkan untuk mempermudah siswa belajar dalam upaya memahami materi pelajaran. Dengan demikian, penggunaan media harus dipandang dari sudut kebutuhan siswa (Suyanti, 2010). Media pembelajaran dipilih dengan memperhatikan prinsip kesesuaian dengan karakteristik peserta didik dan menggunakan media pembelajaran yang bervariasi. Berdasarkan hasil analisis RPP, diketahui bahwa kemampuan mahasiswa dalam menentukan media pembelajaran tergolong sangat baik dengan persentase skor sebesar 92,3\%. Hasil analisis lebih lanjut, Sebanyak 69,2\% mahasiswa menggunakan lebih dari dua media pembelajaran.

Sumber belajar adalah segala sesuatu yang ada disekitar lingkungan kegiatan belajar yang secara fungsional dapat digunakan untuk membantu optimalisasi hasil belajar (Sanjaya, 2010). Melalui sumber belajar yang bervariasi, diharapkan guru dapat memberi perlakuan yang sesuai dengan karakteristik peserta didik yang berbeda-beda. Guru dapat memberikan kesempatan sebanyak mungkin kepada siswa untuk berinteraksi secara aktif dengan sumber-sumber belajar tersebut agar membuahkan pembelajaran aktif bagi setiap siswa (Kusumah W, 2008).

Berdasarkan analisis data diperoleh persentase skor sebesar 71,8 \%. Hal ini menunjukkan kemampuan mahasiswa menggunakan sumber belajar tergolong cukup baik. Hal ini dibuktikan sebanyak lebih dari $80 \%$ 
mahasiswa menggunakan 2 sumber belajar atau lebih (sumber belajar yang bervariasi).

Kegiatan pembelajaran terdiri dari tiga kegiatan yaitu pendahuluan, kegiatan inti dan penutup (Permendikbud No. 24 Tahun 2016 tentang standar proses pendidikan dasar dan menengah). Ada enam aspek yang dianalisis pada komponen kegiatan pembelajaran. Aspek pertama yaitu memuat kegiatan pendahuluan, kegiatan inti dan kegiatan penutup. Berdasarkan hasil analisis data, persentase skor pada aspek ini sebesar $100 \%$ yang menunjukkan bahwa seluruh mahasiswa telah melengkapi tiga kegiatan pembelajaran pada komponen kegiatan pembelajaran.

Aspek kedua yaitu kesesuaian alokasi waktu dengan rincian pengorganisasian. Hasil persentase skor pada aspek ini sebesar $84,6 \%$ yang menunjukkan kemampuan mahasiswa dalam menentukan alokasi waktu dengan rincian pengorganisasian disetiap kegiatan pembelajaran dikategorikan baik. Namun, masih ada beberapa mahasiswa yang kurang tepat dalam mengalokasikan waktu, alokasi waktu tidak sesuai dengan rincian pengorganisasian pada kegiatan inti pembelajaran.

Aspek ketiga yaitu pada langkah kegiatan pembelajaran harus menggambarkan sintaks/tahapan model pembelajaran yang jelas. Hasil persentase skor pada aspek ini sebesar 79,5\% yang menunjukkan kemampuan mahasiswa dalam menggambarkan sintaks/tahapan model pembelajaran yang jelas pada kegiatan pembelajaran dikategorikan cukup baik. Pada aspek ini, langkah-langkah pembelajaran yang disusun beberapa mahasiswa tidak didukung dengan keterangan yang jelas pada setiap tahap pembelajaran sehingga kurang menggambarkan sintaks/tahapan model pembelajaran.

Aspek keempat yaitu merancang kegiatan pendahuluan. Pada kegiatan pendahuluan harus memuat pengkondisian peserta didik, kegiatan religius, apersepsi, motivasi, penyampaian tujuan pembelajaran dan kegiatan yang akan dilakukan. Berdasarkan hasil analisis data, diperoleh persentase skor sebesar 74,4\%. Hal ini menunjukkan bahwa kemampuan mahasiswa dalam merancang kegiatan pendahuluan dikategorikan cukup baik. Pada kegiatan pendahuluan ini, sebagian besar tidak memuat "motivasi", "apersepsi" dan "kegiatan yang akan dilakukan".

Aspek kelima yaitu merancang kegiatan inti. Pada kegiatan inti ini harus memuat kegiatan pembelajaran yang dimulai dari tingkat berpikir rendah ketingkat berpikir tinggi, menggambarkan kemampuan literasi, menggambarkan proses pembelajaran yang menimbulkan interaksi multi arah antar peserta didik, interaksi peserta didik dengan guru dan interaksi dengan bahan/alat/lingkungan belajar, mengembangkan karakter dan mengintegrasi keterampilan abad 21 yang dikenal dengan 4C (Critical Thinking, Creativity, Communication, Colaboration). Hasil persentase skor rata-rata pada aspek ini sebesar $81,5 \%$. Hal ini menunjukkan bahwa kemampuan mahasiswa dalam merancang kegiatan inti tergolong baik.

Berdasarkan hasil wawancara, mahasiswa merasa sulit dalam merancang kegiatan inti. Kesulitan tersebut berkaitan dengan pemilihan model pembelajaran. Jika model pembelajaran yang dipilih sudah cocok, maka mahasiswa akan lebih mudah merencanakan kegiatan literasi, keterampilan abad 21 dan penguatan karakter di setiap tahap kegiatan. Namun, berdasarkan analisis RPP lebih lanjut, kegiatan literasi, pengembangan karakter dan keterampilan abad 21 yang dirancang mahasiswa masih kurang tergambarkan pada kegiatan pembelajaran. Selain itu, mahasiswa mengakui masih belum terlalu memahami bagaimana seharusnya kegiatan literasi, pengembangan karakter dan keterampilan abad 21 tersebut dapat diintegrasikan di kegiatan pembelajaran.

Aspek keenam yaitu merancang kegiatan penutup. Pada kegiatan penutup ini minimal harus memuat kesimpulan, penilaian, tindak lanjut kegiatan dan salam penutup. Berdasarkan hasil analisis data, diketahui bahwa kemampuan mahasiswa dalam merancang kegiatan penutup dikategorikan sangat baik dengan persentase skor sebesar $97,4 \%$. Hanya terdapat 1 mahasiswa yang 
tidak memuat tindak lanjut kegiatan pada kegiatan penutup.

Rancangan penilaian hasil belajar dianalisis berdasarkan 3 aspek yaitu kesesuaian dengan Indikator Pencapaian Kompetensi (IPK), kesesuaian dengan materi pembelajaran dan memuat soal HOTS. Berdasarkan hasil analisis data, persentase skor pada aspek kesesuaian dengan IPK dan kesesuaian dengan materi pembelajaran berturut-turut sebesar $94,9 \%$ dan $97,4 \%$. Hal ini menunjukkan bahwa kemampuan mahasiswa dalam merancang penilaian hasil belajar yang sesuai dengan IPK dan materi pembelajaran tergolong sangat baik.

Sedangkan pada aspek ketiga yaitu memuat soal HOTS diperoleh persentase skor sebesar $66,7 \%$. Hasil ini menunjukkan kemampuan merancang penilaian hasil belajar yang memuat soal HOTS tergolong rendah. Selaras dengan hasil wawancara, mahasiswa mengungkapkan bahwa mereka kesulitan membuat soal dengan tingkatan C4 (menganalisis), C5 (mengevaluasi) dan C6 (mencipta). Berdasarkan lembar kerja bimbingan teknis implementasi kurikulum 2013, menyatakan bahwa penyusunan soal HOTS minimal 10\% dari jumlah soal keseluruhan. Dengan demikian adanya soal HOTS, dapat mengukur kemampuan transfer satu konsep ke konsep lainnya, memproses dan menerapkan informasi, mencari kaitan dari berbagai informasi yang berbeda-beda, menggunakan informasi untuk menyelesaikan masalah, dan menelaah ide dan informasi secara kritis.

Berdasarkan hasil wawancara, rata-rata mahasiswa merasa sulit dalam menyusun teknik penilaian, membuat instrumen penilaian kognitif, afektif dan psikomotorik. Mahasiswa sulit membuat rubrik penilaian afektif dan psikomotorik dan sulit menentukan sikap atau keterampilan apa yang akan dinilai. Sedangkan idealnya, dalam menyusun instrumen penilaian tersebut harus benar-benar dapat mengukur kemampuan kognitif, afektif dan psikomotorik sesuai dengan IPK dan tujuan pembelajaran yang akan dicapai. Hal inilah yang juga menyulitkan mahasiswa dalam menyusun instrumen penilaian.

\section{SIMPULAN DAN SARAN}

Berdasarkan hasil penelitian analisis data yang sudah dilakukan, maka disimpulkan bahwa kemampuan mahasiswa calon guru Program Studi Pendidikan Sosisologi FKIP Untan dalam merancang RPP sesuai kurikulum 2013 sebagai berikut: 1) menuliskan Kelengkapan identitas RPP kategori sangat baik, 2) kelengkapan komponen RPP kategori sangat baik, 3) rumusan KI, KD, dan IPK kategori kurang, 4) rumusan tujuan pembelajaran kategori kurang, 5) materi ajar kategori cukup, 6) model/metode pembelajaran kategori baik, 7) media Pembelajaran kategori sangat baik, 8) sumber belajar kategori baik, 9) kegiatan pembelajaran kategori baik, dan 10) rumusan penilaian hasil belajar kategori baik. Berdasarkan simpulan penelitian di atas, maka bagi mahasiswa praktikan PPL disarankan sebagai berikut: 1) hendaknya memiliki motivasi yang kuat dalam mengajar, 2) wajib mengkonsultasikan administrasi pembelajaran kepada guru pamong agar proses pembelajaran berjalan dengan bai, 3) harus lebih tegas dan menunjukkan kewibawaannya sebagai seorang guru agar para siswa segan dan menghormati layaknya gurunya sendiri bukan teman, dan 4) melengkapi sarana dan prasarana pembelajaran agar kegiatan belajar mengajar dapat berjalan dengan baik. Bagi Unit PPL, selama pelaksanaan PPL di sekolah mitra hendaknya mahasiswa PPL dibebaskan dengan kuliah di kampus karena mengingat waktu dan jarak dari sekolah ke kampus yang jauh dan mahasiswa PPL harus datang ke sekolah setiap hari. Dengan pembebasan kuliah di kampus, mahasiswa PPL bisa fokus pada kegiatan PPL tanpa harus ada beban kuliah di kampus agar pelaksanaan PPL di sekolah berjalan tanpa hambatan yang berarti. Bagi LPTK, pemberian bekal secara efektif terutama dalam mata kuliah pengajaran mikro kepada mahasiswa calon peserta PPL agar pelaksanaan PPL di sekolah mitra dapat optimal. Perlunya monitoring secara efektif dari dosen pembimbing dan kerjasama yang baik dengan guru pamong agar kendala-kendala yang ditemui oleh mahasiswa PPL dapat diminimalisir. 


\section{DAFTAR RUJUKAN}

Ambarawati, M. 2016. Analisis Keterampilan Mengajar Calon Guru Pendidikan Matematika pada Mata Kuliah Micro Teaching. Jurnal Pedagogia ISSN 2089-833 Vol. 5, No. 1, 8189.

Arikunto, S. 2010. Prosedur Penelitian Suatu Pendekatan Praktek. Jakarta: Penerbit Rineka Cipta.

Fathurrohman, P. 2012. Guru Profesional. Bandung: PT. Refika Aditama.

Ibrahim. 2017. Deskrips Implementasi Kurikulum 2013 dalam Proses Pembelajaran Matematika di SMA Negeri 3 Maros Kabupaten Maros. Jurnal Daya Matematis. 3(3), 370 - 378.

Kadiriandi, R dan Ruyadi, Y. 2017. Pengaruh Penerapan Model Pembelajaran Model Two Stay Two Stray (TSTS) terhadap Peningkatan Keaktifan dan Hasil Belajar Sosiologi di SMA Pasundan 3 Bandung. Jurnal SOSIETAS, Vol. 7, NO. 2, 2017, $429-433$.

Kharisma, F. N dan Hariyatmi. 2015. Kemampuan Pedagogical Knowledge (PK) Calon Guru Biologi FKIP UMS dalam Menyusun RPP Tahun Ajaran 2015/2016. Prosiding Seminar Nasional Pendidikan Biologi dan Saintek.

Kosasih, E. 2014. Strategi Belajar dan Pembelajaran. Bandung: Penerbit Yrama Widya.
Kustijono, R dan Wiwin, E. 2014. Pandangan Guru Terhadap Pelaksanaan Kurikulum 2013 dalam Pembelajaran Fisika SMK di Kota Surabaya. Jurnal Pendidikan Fisika dan Aplikasinya (JPFA). 4(1), 1 - 14.

Mulyasa, E. 2014. Guru dalam Implementasi Kurikulum 2013. Bandung: PT Remaja Rosdakarya.

Sanjaya, Wina. 2010. Strategi Pembelajaran Berorientasi Standar Proses Pendidikan. Jakarta: Prenada Media Group.

Saragih, H. 2016. Meningkatkan Keterampilan Guru Membuat Perangkat Pembelajaran Berbasis Kurikulum 2013 bagi Guru pada Sekolah. JUPIIS: Jurnal Pendidikan Ilmu ilmu Sosial. 8(2), 114 - 122.

Sari, D. P. 2013. Kendala-Kendala Pelaksanaan Program Pengalaman Lapangan (PPL) Mahasiswa FKIP UNS di SMK Negeri 1 Sukoharjo Tahun 2012. Jupe UNS, Vol 2, No 1, Hal 26 s/d 38.

Sholeh, M. 2017. Perencanaan Pembelajaran Mata Pelajaran Geografi Tingkat SMA dalam Konteks KTSP. Jurnal Geografi, 4(2), 129 137.

Suyanti, R. D. 2010. Strategi Pembelajaran Kimia. Yogyakarta: Graha Ilmu. 